\title{
Marie-Françoise Christout, Le ballet de cour de Louis XIV. 1643-1672. Mises en scène
}

Daniela Dalla Valle

\section{(2) OpenEdition}

\section{Edizione digitale}

URL: https://journals.openedition.org/studifrancesi/26231

DOI: 10.4000/studifrancesi.26231

ISSN: 2421-5856

\section{Editore}

Rosenberg \& Sellier

\section{Edizione cartacea}

Data di pubblicazione: 1 avril 2007

Paginazione: 173

ISSN: 0039-2944

\section{Notizia bibliografica digitale}

Daniela Dalla Valle, «Marie-Françoise Christout, Le ballet de cour de Louis XIV. 1643-1672. Mises en scène», Studi Francesi [Online], 151 (LI | I) | 2007, online dal 30 novembre 2015, consultato il 22 novembre 2021. URL: http://journals.openedition.org/studifrancesi/26231 ; DOI: https://doi.org/ 10.4000/studifrancesi.26231

Questo documento è stato generato automaticamente il 22 novembre 2021.

\section{(c) 9 (i) $\Theta$}

Studi Francesi è distribuita con Licenza Creative Commons Attribuzione - Non commerciale - Non opere derivate 4.0 Internazionale. 


\title{
Marie-Françoise Christout, Le ballet de cour de Louis XIV. 1643-1672. Mises en scène
}

\author{
Daniela Dalla Valle
}

NOTIZIA

MARIE-FRANÇOISE CHRISTOUT, Le ballet de cour de Louis XIV. 1643-1672. Mises en scène, Paris, Picard, 2005 («La vie musicale en France sous les rois Bourbons», n. 34).

1 Il volume, presentato da André Chastel, analizza il balletto di corte in un momento particolare della sua storia: sotto il regno di Luigi XIV. L'autrice si sofferma in primo luogo sulla ricerca di uno stile, durante la Reggenza; passa poi al periodo 1653-1660, in cui prevalgono un gusto prezioso e un'attrazione per il fantastico; fissa poi il trionfo del fasto, nel balletto dal 1660 al 1672. Nel capitolo quinto, l'autrice si sofferma sui teorici (Michel de Pure, C.-F.Ménestrier, Hédelin d'Aubignac) e conclude il suo studio analizzando le diverse componenti del balletto (musica, danza, costumi, messa in scena). Alcuni interessanti annessi e una ricca bibliografia completano il volume, oltre a una bella documentazione illustrativa. 